\title{
Big five personality factors and emotional intelligence among university students: A gender perspective
}

Abbas, Munir

Government College University, Lahore, Pakistan (munirabbas@gmail.com)

Khan, Muhammad Nauroze $\square$

Government College University, Lahore, Pakistan (Thehope51214@gmail.com)

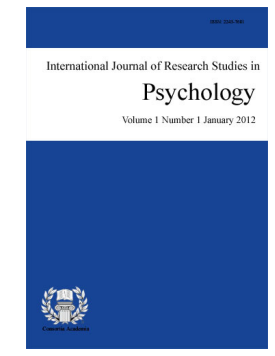

ISSN: $2243-7681$ Online ISSN: 2243-769X

OPEN ACCESS

\section{Abstract}

Students are the assets of a country. Personality traits and emotional intelligence are two important factors in study setting and also in career. Purpose of the study was to investigate the gender differences on big five personality traits and emotional intelligence of the university students. The data were collected from different institutes of Lahore, Pakistan. Sample size consists of (300) students in which 150 were male participants and 150 were female participants. Two questionnaires were administered, Wong and law Emotional Intelligence scale was used to measure emotional intelligence while NEO-FFI were used to measure personality traits. It has been found that there was no gender difference regarding any of the variables used in study. Limitations and implications with future suggestions are discussed in the Pakistani Context.

Keywords: personality traits; emotional intelligence; students 


\section{Big five personality factors and emotional intelligence among university students: A gender perspective}

\section{Introduction}

Now a days there is a challenge for students that how to get success in their academic life. There is a challenge that how to meet current change and demands or environmental needs. There is a huge competition in that era. In these changes humane behavior significantly differ (Piderit, 2000). Change in the surroundings and these environmental or societal demands are due to different personality traits and different level of emotional intelligence. Personality traits predict human behavior. Personality traits describe that a person is talkative, warmth, success seeker, achievement oriented, depressed or tense. On the basis of above discussion personality traits and emotional intelligence are the basic and important factor in the development of student life and their success in their academic life and also in their career (Beer \& Nohria, 2000).

According to Rooy and Viswesvaran (2004) this issues and describes that although there are many issues and opinion regarding this constructs, it has major role in performance or success. This concept is not a new concept. Its origin starts from the Thorndike concept of social intelligence (Thorndike, 1920). It is essential to enhance positive personality traits and also enhance the level of emotional intelligence in student. So that they can meet academic demands and get success in their life by increasing their potential to compact with society and its needs.

Personality traits and emotional intelligence are related constructs as emotional intelligence has a concept of understanding and control of personality formation or construction. Some theories of emotional intelligence is closely related to the theories of personality such mix model of emotional intelligence which define emotional intelligence as personality traits and also as intellectual characteristics (Bar-on, 2005; Goleman, 1995). In both theories of emotional intelligence we discussed those areas which we have already discussed under the personality theories. Emotional intelligence model given by the Mayer and Salovey which is also known as the pure model or ability model of emotional intelligence is also have similar characteristics with some sub component of personality traits model such as agreeableness and openness to experience (Bracket and Mayer, 2003).

In this study we investigate the relationship between personality traits and emotional intelligence, gender differences on both variables and also the prediction of emotional intelligence by the personality traits. First of all we will discuss personality, its approaches and then trait theory. Secondly we discuss emotional intelligence, its models and its measures. Then we add relationship studies, objectives, significance and hypothesis.

\subsection{Concept of Personality}

Personality takes a lot of attention in these days due to its measurement of individual differences and similarities in order to get success in educational life and also in professional life. Personality measures the abilities of a person that how good he will so the task assign to him (Sackett, Gruys, \& Elligson, 1998). Personality traits are the characteristics of a person which remain stable throughout his life career and on the basis of their consistency we predict the behavior of an individual (Myers, 1998).

Personality consists of both similarities and individual differences of an individual through which he compasses his life and achieves his life goals. Similarities reflect universal factors of human nature while difference affects major parameters of human behavior and performances. Furthermore he describe inside perspective and outside social interaction manner. Inside perspective consist of needs, statues, acceptance and ability to do something while social interaction describes the reputation of a person in Interacting with others. 
Inside identities explain a person performance while outside identity predicts a person performance (Hogan \& Shelton, 1998). Personality means individual differences or characteristics among people. Personality is a strong organizational system within psycho-physical system that describes individual behavior and thoughts (Allport, 1937).

The big five personality factor model which is also known by "five factor model" or "Big five" is mostly workable theory from last two decades. Five factor model explain human nature or personality in five dimension which are comprehensives and meaningful to explain individual differences (McCrae \& Costa, 1986; Mount \& Barrack, 1998). Five factor model of personality is a model which describes personality in terms of five major clauses and these clauses are not on the basis of any single theory of personality. These clauses consist of all those characteristics which are necessary and are sufficient to describe a whole personality of an individual (Costa \& McCrae, 1985). Although many writers consider five factor model insufficient to summarize all individual differences of a personality, evidences shows that it is good to measure personality in different cultures and for different age groups e.g. child, Adult, rating sources as well as self-reports.

Five dimension of five factor model is given as, Extraversion, Neuroticism, Agreeableness, Conscientiousness, Openness to Experience. It is dimension of personality which describe about a person that is he talkative, sociable assertive, energetic, outgoing, active, quite, reserved, silent and many others. Extraversion is important to study due to there is important to study due to three reasons. First it is a dimension of personality (Costa \& McCare, 1992; Digman, 1990). Second it describes effective functioning and well-being in social setting (Ozer \& Benet-Martinez, 2006). Third reason to study extraversion is ability to predict risk and resilience for different Psychopathologist (Trull \& Sher, 1994; Widiger, 2005). Extraversion is an ability which shows that person focuses on external world while a person which lacks this quality means introvert focus on inner world and thoughts.

Neuroticism dimension of personality explains emotional stability of person high scores on neuroticism show danger of severe Pathology or Psychological problem. High scores show four, sadness, Anxiety, tense, Irritability, depression, anger, guilt, embarrassment etc. Low scores on neuroticism show emotional stability of a person. According to Hormann and Maschke (1996) Neuroticism is the predictor of success or performance. Agreeableness shows co-cooperativeness of an individual. High score shows that person is co-operative, sympathetic to others, Trustworthy and anger to help others. While low scores show that person is competitive rather than co-operative, selfish and lack of empathy. According to Salgado (1997) agreeableness shows success in life, co-operative nature support or help in team-working. Less agreeable persons are proving their selves goods as managers.

Conscientiousness shows competency of an individual. High scores show efficiency, working in organized manner, self-discipline and active in planning process. It shows to complete a task in an organized and effective manner. High score shows hard working, goal oriented while low scores show criminal behavior, lack of success or lack of goal orientation and involve in anti-social activities.

Openness to experience has six factors or dimension. These six dimensions are imagination or fantasy, attentiveness to inner feelings, aesthetic sensitivity, intellectual curiosity, adventurousness and performance for variety. High scores show loves to fantasize or have a creative imagination, aware of their own feelings. Appreciate arts or have interests in arts, loves traveling or visit new places of try new things, question or challenge traditional values or authority, loves to play with ideas or loves to debate, engage in intellectual discussions. Low scores show preference to facts rather than imagination, not so good to express their emotions and also not aware about their emotions, No interested in arts, prefer routine, follow traditions and rules and think that intellectual discussions are waste of time.

\subsection{Concept of Emotional Intelligence}

Although emotional intelligence is so popular in these days but these are also some debates about its 
conceptualization, assessment and further its predictability and applicability between researchers and practitioners. Van Rooy and Viswesvaran (2004) examined this issue and describe that although there are many issues and opinion regarding this construct, it has major role in performance or success. Prior to forming hypothesis, his background, conceptualization and importance of this construct is explained in literature. In first section we describe the historical background of the construct which gives overview its history. In second section we describe different concepts about emotional intelligence especially concepts of its three major protagonists e.g. Mayer-Salovey-Caruso, Goleman, and Bar-on. And at last we discuss importance of emotional intelligence regarding its measurement and predictive validity. Importance of the construct depends on its predictive ability which is useless without its measurement. Measurement of this construct depends on its conceptualization or how we can operationalize it. Also distinction between trait emotional intelligence and ability emotional intelligence lies in the concept that how we can operationalize this construct.

Origins of emotional intelligence started from Thorndike period. He first used the word social intelligence. According Thorndike (1920) intelligence can be divided into three types mechanical, abstract and social. Mechanical intelligence means the intelligence which is used in mechanical work or physical work or things which a person does. Abstract intelligence is related to the ideas and understanding themes related to the ideas.. This intelligence helps us to maintain good relationship with others. For the first time term emotional intelligence used in German language by Leuner (1966) while in English language by Payne (1984). This term introduce as main stream in Psychology in 1990 by Mayer and Salovey (Mayer, Dipaole, \& Salovey, 1990; Salovey \& Mayer, 1990).

Emotional intelligence term was first introduced in 1990 as scientifically by Mayer and Salovey. This is more highlighted by denial Goleman when he wrote his book "emotional Intelligence". Environmental Intelligence is defined differently by different theorists and each of them gives Model of emotional Intelligence based on their theories. Daniel Goleman defines emotional Intelligence as "Emotional Intelligence refers to the ability to recognize and regulate emotions in ourselves and others" (Goleman, 2001). Peter Salovey and John Mayer defined emotional Intelligence as "A form of Intelligence that involves the ability to monitor one's own and others feelings and emotions, to discriminate among them and to use this information to guide one's thinking and actions" (Salovey \& Mayer, 1990). Reuven Bar-on emotional Intelligence as being concerned with understanding oneself and others, relation to People, adapting to and coping with immediate Surroundings to be more successful in dealing with environmental demands (Bar-on, 1997).

Gardner (1993) categorized intelligence into seven domains and gives the idea of interpersonal and intrapersonal intelligence which is closely related to emotional intelligence. He describe interpersonal intelligence is ability to deal with other's mood, temperament, intensions and motivation. Also he describe intrapersonal intelligence is the ability to deals one-self, inner feelings and inner-motivation. Sternberg and Grigornko (2000) gives the concept of particle intelligence which means that a type of intelligence which deals with real or practical problems of life which are not related to mental abilities that are measured by IQ test.

Regardless all discrepancies one thing is common that emotional Intelligence is differed from Standard Intelligence of I.Q. These Models based on two types Ability Model and Mixed Model of Emotional Intelligence. Emotional intelligence became popular in order to fulfill gap which was not covered by the traditionally define intelligence (Goldstein, Zedeck, \& Goldstein, 2002). It is possible that traditional intelligence may give single theoretical answer across world but it fails to cover daily or routine life where emotions exist or emotions has major role (Zee \& Abeke, 2004).

Evidences regarding gender differences are contradictory. According to Goleman (1996) there is no effect of gender on overall emotional intelligence but it may in any area of emotional intelligence. According to Mayer and Geher (1996) women have high score than males in any measure of emotional intelligence. Mayer, Caruso and Salovey (1999) also describe similar results that women have high scores on measure of emotional intelligence than males. Mandell and Pherwan (2003) conducted research and describe that females scores are 
high than males.

Mishra and Ranjan (2008) investigated the effect of gender differences on emotional intelligences. Sample size of 80 participants was used in which 40 were males and 40 were females. Results indicate that gender difference effect emotional intelligence males have high score than females which shows that males have more resistant power against difficulties and to control and manage stress and their emotions in more positive way.

Mohanty and Devi (2010) conducted study on gender difference. Sample size of 60 girls and boys were used. Result indicates that girls have higher scores than boys. Which means girls are positive, optimistic and well aware of their emotions than boys? Nasar and Nasar (2008) conducted study using sample size of 200 participants 100 males and 100 females. Their age rang were 17 to 20 years. In comparison with males, female's scores were high in emotional intelligence. Brackett, Mayer and Warner (2004) conduct research on college students having sample size of 330 students males score was low than females. This show males engagement in negative activities than females such as alcohol, drugs, and many others.

There are also some studies which show no significant gender differences. Pant and Prakash (2004) investigated gender difference on Indian sample. Sample size was 60 participants 30 males and 30 females. Multifactor emotional intelligence scale was used. Participants were approached personal human resource department, students of post-graduation. Results indicate that there were no significant gender differences regarding emotional intelligence. Tyagi (2004) conducted research of secondary school teacher to examine effect of gender differences on emotional intelligence. Results indicate that there were no significant gender differences.

\subsection{Theoretical framework}

We are using five factor model due to following reason, first reason of using five factor model is because in our research we considering emotional intelligence as trait emotional intelligence which is closely related to the personality traits model. Second reason based on the study of Salgado (2003) in which he compares the criterion validity of different types of test which measure personality with five factor model of personality and he concluded that five factor model is most appropriate and suitable to measure personality among all of them. Emotional intelligence is defined in two ways. A scientist who belongs to Intelligence studies believes that it should be measured according to mental and cognitive ability. While other scientists who belong to personality studies define emotional intelligence as traits which should be measured though self- report measures. Petridis and Furnham (2001) suggested differentiating these two measures by naming it as "ability EI" and "traits EI". Traits emotional intelligence has large significant relationship with extra-version and neuroticism while it has significant positive relationship with conscientiousness, openness and agreeableness (Petrides, \& Furnham, 2001; Schutte, Malouff, Hall, Haggerty, Cooper, Golden, et al., 1998). While ability emotional intelligence can be measured through performance test and it is not expected that it has strong correlation with personality factor. It is strongly co-related with general cognitive ability.

In this study we want to measure the relationship of personality traits with emotional intelligence. On the bases of above discussion we used five factor models to measure personality while trait emotional Intelligence is used to measure emotional intelligence.

\subsection{Objectives of the Study}

Present study helps us to find out gender differences on big five personality traits and emotional intelligence.

\subsection{Significance of the Study}

This study is important due to many reasons. First of all, Theoretical importance of the constructs was used in the study. Secondly personality traits in general and emotional intelligence specifically are considered the 
Abbas, M., \& Khan, M. N.

predictors of success in academic and social life. Thirdly, the results of this study can ensure the development of the components of emotional intelligence and personality traits improving student's success in Pakistan.

\subsection{Hypothesis}

The following research hypotheses were formulated to guide research objective:

H1: There would be significant gender differences on emotional intelligence and personality traits

H2: personality traits (agreeableness, openness to experience, extraversion, conscientiousness and neuroticism) would be significantly predictor of emotional intelligence.

\section{Methodology}

\subsection{Sample}

Convenient sampling strategy was used to collect sample. Sample size consists of 300 students (150 male and 150 female). Age of the students ranged from 18-26 and Sample Consists of Intermediate, graduate and post graduate students. Sample is collected from government college university Lahore, University of Lahore, Global institute of business administration and Aiman institute of medical sciences. Informed consent is taken from all students.

\subsection{Instruments}

There were two instruments used in our current research given as follows.

NEO Five Factor Inventory Scale - It was developed by Costa and McCrae (1992) and used to measure personality traits e.g. agreeableness, Neuroticism, openness, extraversion and conscientiousness. Alpha reliabilities of NEO-FFI were ranged from 79 to 83 and conscientiousness possessed highest reliability among all. NEO-FFI is a five point Likert scale from strongly agree to strongly disagree. It consists of 60 items in which each of five domains consists of twelve terms.

Wong and Law Emotional Intelligence scale - It was developed by Wong and Law. It was used to measure emotional intelligence. It was seven point Likert scale from strongly disagree to strongly agree. Internal consistency reliability of the scale as reported by Wong and Law was quite good $(r=.79)$. High score shows high emotional intelligence.

\subsection{Procedure}

Convenient sampling technique was used in data collection. Data collection has been done through survey form. Participants were personally contacted in class-room or at cafeteria. They were brief about study objectives and informed consent was also taken from students. Information was taken in demographic sheet as well as questionnaire in written form and also with oral instructions. Participants were assured about confidentiality of the information.

\subsection{Statistical analysis}

Descriptive and inferential analyses were carried out t-test analysis was used to analyze data.

\section{Results}

Results of present study depicts that there is no significant gender differences on big five personality traits and emotional intelligence (see table 1). 
Big five personality factors and emotional intelligence among university students: A gender perspective

Table 1

Mean Differences on the Personality Traits and EI between Men and Women $(N=300)$

\begin{tabular}{|c|c|c|c|c|c|c|c|c|c|}
\hline \multirow[t]{2}{*}{ Variable } & \multicolumn{2}{|c|}{$\stackrel{\text { Men }}{(n=150)}$} & \multicolumn{2}{|c|}{$\frac{\text { Women }}{(n=150)}$} & \multirow[t]{2}{*}{$t(298)$} & \multirow[t]{2}{*}{$p$} & \multicolumn{2}{|c|}{$95 \% C I$} & \multirow{2}{*}{$\begin{array}{l}\text { Cohen' } \\
\text { s } d\end{array}$} \\
\hline & $M$ & $S D$ & $M$ & $S D$ & & & $L L$ & $U L$ & \\
\hline Consciousness & 42.52 & 4.59 & 43.26 & 4.39 & -1.43 & .155 & -1.76 & .28 & .16 \\
\hline Agreeableness & 42.00 & 4.68 & 42.15 & 5.05 & -.27 & .785 & -1.26 & .95 & .03 \\
\hline Openness & 41.23 & 4.80 & 41.47 & 4.14 & -.46 & .643 & -1.25 & .79 & .05 \\
\hline Extraversion & 40.93 & 4.86 & 40.39 & 4.61 & .99 & .324 & -.53 & 1.62 & .11 \\
\hline Neuroticism & 38.60 & 6.01 & 39.81 & 6.14 & -1.72 & .086 & -2.58 & .17 & .19 \\
\hline Emotional intelligence & 85.78 & 11.72 & 86.32 & 12.19 & -.39 & .696 & -3.25 & 2.18 & .04 \\
\hline
\end{tabular}

Note . $\mathrm{CI}=$ confidence interval. $\mathrm{LL}=$ lower limit. $\mathrm{UL}=$ upper limit.

\section{Discussion}

Our hypothesis that there would be significant gender differences on big five personality traits and emotional intelligence is rejected. Our research shows no significant gender differences which are supported by literature review that Tyagi (2004) conducted research of secondary school teacher to examine effect of gender differences on emotional intelligence. Results indicate that there were no significant gender differences. In order to measure effect of gender on emotional intelligence, a study is conducted by Mathur, Malhotra, and Dube (2005) on high school students having age from 13 to 15 years. The results of study revealed independent of gender on the dimension of emotional intelligence. While, Depape, Hakim-Larson, Voelker, and Page (2006) conducted research on gender differences sample size of 126 participants 42 males and 84 females. Study concluded that there is no significant gender difference regarding emotional intelligence. There are also some contradictory studies some of which shows that males have higher scores and some of which shows females have higher scores.

Brackett, Mayer, and Warner (2004) conduct research on college students having sample size of 330 students males score was low than females. According to Ciarrochi, Chan, and Bajgar (2001) female's scores were higher than males which means females are more emotionally stable than males. Hunt and Evans (2004) investigated gender differences on individuals having traumatic experiences. Sample size of 414 participants was used. Results revealed higher scores of males than females. Carr (2009) conducted research on medical schools to find out gender differences. Sample size of 177 participants was used. Results revealed that male's candidates have high scores than female candidates.

Along with this, there are no significant gender differences on personality traits. Results support our findings as Kant (2014) conducted research to measure relationship between personality traits and emotional intelligence of secondary teacher in India. Finding of the study describe that there are no significant gender differences on personality traits. Ghiabi and Besharat (2011) conducted research to investigate relationship between personality dimensions and emotional intelligence. Sample size of 440 participants was used. Findings of the study describe that there were no gender differences regarding any of the variable of the study. There are also some contradictory studies regarding gender differences on personality traits. Rehmani and lavasani (2012) conducted study on gender differences in five factor model of personality and sensation seeking. Results of the study describe that there were significant gender differences between male and female. Females showed higher scores then males on openness to experience and agreeableness.

\subsection{Limitations}

Firstly, sample size was too short which cannot be generalized to the whole population. Secondly, sample was collected from one city. Thirdly only two variables were studied. Fourthly, Instruments used in our study was in English language which may affect response accuracy by the participants and is also a foreign instrument which may not match with our culture. 


\subsection{Future research recommendations}

Future researches would like to conduct research on relation of personality traits and emotional intelligence with a large sample size. Future researchers may add one or two another variables for further studies. These findings may not applicable in others cultures due to cultural differences. It may study in different cultural settings in future. This study was on students, future researcher may conduct research in other areas such as teachers, managers and on leaders.

\subsection{Practical Implication}

Present research may insight and awareness to students. It helps students to increase their efficiency by making high scores on emotional intelligence. It may help further studies in different cities of Pakistan as a basic data. It may helpful government or different educational institution to regulate programs that increase efficiency of students, academic achievement and emotional intelligence.

\section{References}

Allport, G. W. (1937). Personality: A psychological interpretation. New York: H. Holt and Company.

Andi, H. K. (2012). Emotional intelligence and personality traits: A correlational study of MYEIT and BFI. International Journal of Academic Research in Business and Social Sciences, 2(10), 285-295.

Athota, V. S., O'connor, P. J., \& Jackson, C. (2009). The role of emotional intelligence and personality in moral reasoning. European Journal of Personality Research, 11, 453-470.

Austin, E. J., Evons, P., Goldwater, R., \& Potter, V. (2005). A preliminary study of emotional Intelligence, empathy and exam performance in first year medial students, Personality and Individual Differences, 39(8), 1395-1405. https://doi.org/10.1016/j.paid.2005.04.014

Bar-On, R. (1997). Bar-On Emotional Quotient Inventory (EQ-I): Technical Manual. Toronto, Canada: Multi-Health Systems.

Bar-On, R. (2002). Bar-On Emotional Quotient Inventory (EQ-I): Technical Manual.Toronto, Canada: Multi-Health Systems.

Bar-On, R. (2005). Emotional intelligence and subjective wellbeing. Perspective in Education, 23(1), 1-22.

Beer, M., \& Nohria, N. (2000). Cracking the code change. Harvard Business Review, 78(3), 133-141.

Beshart, M. A. (2010). The relationship between emotional intelligence and self-efficacy and academic success. Education Renovation Journal, 2(10), 1-10.

Boatzis, R. E., Goleman, D., \& Rhee, K. (1999). Clustering competence in emotional intelligence: Insights from the Emotional Competence Inventory (ECI). In R. Bar-On \& J. D. Parker (Eds.), Handbook of emotional intelligence (pp. 343-362). San Francisco: Jossey-Bass.

Brackett, M. A., \& Mayer, J. D. (2003). Convergent, discriminant, and incremental validity of competing measures of emotional intelligence. Personality and Social Psychology Bulletin, 29(10), 1-12. https://doi.org/10.1177/0146167203254596

Brackett, M. A., Mayer, J. D., \& Warner, R. M. (2004). Emotional intelligence and its relation to everyday behaviour. Personality and Individual differences, 36(6), 1387-1402. https://doi.org/10.1016/S0191-8869(03)00236-8

Brackett, M. A., Warner, R. M., \& Basco, J. S. (2005). Emotional Intelligence and relationship quality among couples. Personal Relationships, 12(2), 197-212. https://doi.org/10.1111/j.1350-4126.2005.00111.x

Bradberry, T., Greaves, J., Emmerling, R., Sanders, Q., Stamm, S., Su, L. D., \& West, A. (2003). Emotional Intelligence Appraisal: Technical manual. Talent Smart Inc.

Carr, S. E. (2009). Emotional intelligence in medical Student: Does it correlate with selection measures? Medical Education, 43(11), 1069- 1077. https://doi.org/10.1111/j.1365-2923.2009.03496.x

Carroll, J. B. (1993). Human cognitive abilities: A survey of factor analytic studies. New York: Cambridge University Press. https://doi.org/10.1017/CBO9780511571312 
Big five personality factors and emotional intelligence among university students: A gender perspective

Cattell, R. B. (1950). Personality: A systematic, theoretical and factual study. New York: McGraw. https://doi.org/10.1037/10773-000

Charbonneau, D., \& Nicol, A. A. (2002). Emotional intelligence and prosocial behaviors in adolescents. Psychological Reports, 90(2), 361-370. https://doi.org/10.2466/pr0.2002.90.2.361

Chen Y. T., \& Lai, C. S. (2015). Personality traits, emotional intelligence and academic achievements of university students. American Journal of Applied Psychology, 4(3), 39-44. https://doi.org/10.11648/j.ajap.s.2015040301.17

Christopher, H., Kamlesh S. \& Brett, L. (2011). The happy personality in India: The role of emotional intelligence. Journal of Happiness Study, 12, 807-817. https://doi.org/10.1007/s10902-010-9228-4

Ciarrochi, J., Chan, A. Y., \& Bajgar, J. (2001). Measuring emotional intelligence in adolescents. Personality and individual differences, 31(7), 1105-1119. https://doi.org/10.1016/S0191-8869(00)00207-5

Costa, P. T. Jr., \& McCrae, R. R. (1985). The NEO Personality Inventory manual. Odessa, FL: Psychological Assessment Resources.

Costa, P. T., \& McCrae, R. R. (1992). Four ways five factors are basic. Personality and Individual Differences, 13(6), 653-665. https://doi.org/10.1016/0191-8869(92)90236-I

Dawda, D., \& Hart, S. D. (2000). Assessing emotional intelligence: reliability and validity of the Bar-On Emotional Quotient Inventory (EQ-i) in university students. Personality and Individual Differences, 28, 797-812. https://doi.org/10.1016/S0191-8869(99)00139-7

Depape, Anne- Marie R., Hakim-Larson, J., Voelker, S., \& Page, S. (2006). Self-talk and emotional intelligence in university students. Canadian Journal of Behavioural Science, 38(3), 250-260. https://doi.org/10.1037/cjbs2006012

Devi, U., \& Rayal, K. (2004). Adolescent's perception about family environment and Emotional intelligence. Indian Psychological Review, 62(3), 157-167.

Digman, J. M. (1990). Personality structure: Emergence of the five-factor model. Annual Review of Psychology, 41, 417-440. https://doi.org/10.1146/annurev.ps.41.020190.002221

Funder, D. C. (2004). The personality puzzle (3rd ed.). New York: W. W. Norton.

Gardner, H. (1993). Frames of mind: The theory of multiple intelligences (10th ed.). New York: Basic Books.

Ghiabi, B., \& Ali Besharat, M. (2011). Emotional intelligence, alexithymia, and interpersonal problems. Procedia - Social and Behavioral Sciences, 30, 98-102. https://doi.org/10.1016/j.sbspro.2011.10.020

Goldstein, H. W., Zedeck, S., \& Goldstein, I. L. (2002). Is this your final answer. Human Performance, 15, 123-142. https://doi.org/10.1080/08959285.2002.9668087

Goleman, D. (1995). Emotional intelligence. New York: Bantam Books.

Goleman, D. (1998). Working with emotional intelligence. New York: Bantam Books.

Goleman, D. (2001). Emotional intelligence: Issues in paradigm building. In C. Cherniss \& D. Goleman (Eds..), The emotionally intelligence workplace (pp. 25-30). San Francisco: JosseyBass.

Higgs, M. (2001). Is there a relationship between Myers-Briggs Type Indicator (MBTI) and emotional intelligence? Journal of Managerial Psychology, 16(7), 509-533. https://doi.org/10.1108/EUM0000000006165

Hogan, R., \& Shelton, D. (1998). A socioanalytic perspective on job performance. Human Performance, 11, 129-144. https://doi.org/10.1080/08959285.1998.9668028

Hörmann, H., \& Maschke, P. (1996). On the relation between personality and job performance of airline pilots. The International Journal of Aviation Psychology, 6, 171-178. https://doi.org/10.1207/s15327108ijap0602_4

Hudani, N., Redzuan, M., \& Hamsan, H. (2012). Inter relationship between emotional intelligence and personality trait of educator leaders. International Journal of Academic Research in Business and Social Sciences, 2(5), 223-237.

Hunt, N., \& Evans, D. (2004). Predicting traumatic stress using emotional intelligence. Behaviour Research and Therapy, 42(7), 791-798. https://doi.org/10.1016/j.brat.2003.07.009

Iruloh, B. R. N., \& Ukaegbu, H. M. (2015). Emotional, social, cognitive, intelligence and social support network among youth. British Journal of Physical Research, 3(2), 35-41. 
Abbas, M., \& Khan, M. N.

Jadhav, S. G., \& Havalappanavar, N.B. (2009). Effect of Yoga Intervention on Anxiety and Subjective well-being. Journal- Indian Academy of Applied Psychology, 35(1), 27-32.

Kafetsios, K. (2004). Attachment and emotional intelligence abilities across the life course. Personality and Individual Differences, 37(1), 129-145. https://doi.org/10.1016/j.paid.2003.08.006

Kant, R. (2014). Interrelationship between personality traits and emotional intelligence of secondary teachers in India. International Journal of Evaluation and Research in Education, 3(3), 158-168. https://doi.org/10.11591/ijere.v3i3.6145

Kappagoda, U. W. M. R. S. (2013), English teachers' emotional intelligence \& its impact on their organizational citizenship behavior. International Journal of Research in Commerce and Management, 2(9), 18-22.

Khaef, E. A., Motaqi, P., Hasand Z. H., \& Habibi, T. Z. (2011). Explanation of the influence of personality characteristics on organizational commitment regarding the role of leadership styles. Quarterly of Management Research, 1, 71-78.

Lassen, R. J., \& Buss, D. M. (2005). Personality psychology: Domains of knowledge about human nature (2nd ed.). New York: McGraw Hill.

Leuner, B. (1966). Emotional intelligence and emancipation. Praxis Kinder psychology, 15, 193-203.

Mahasneh, A. M. M. (2013). Investigation relationship between emotional intelligence and personality traits among sample of Jordanian university students. Canadian Academy of Oriental and Occidental Culture, 9(6), 82-86.

Mandell, B., \& Pherwani, S. (2003). Relationship between emotional intelligence and TL style: A gender comparison. Journal of Business \& Psychology, 17(3), 387-404. https://doi.org/10.1023/A:1022816409059

Mathur M., Malhotra, B., \& Dube, S. (2005) Gender differences on emotional intelligence and scholastic achievement in school going adolescents. Indian Psychological Review, 64(3), 133-136.

Matthews, G., Emo, A. K., Funke, G., Zeidner, M., Roberts, R. D., Costa, Jr, P. T., \& Schulze, R.(2006). Emotional Intelligence, personality and task-induced stress. Journal of Experimental Psychology, 12(2), 96-107. https://doi.org/10.1037/1076-898X.12.2.96

Mayer J. D. (2000). Emotion, intelligence, emotional intelligence. In J. P. Morgan (Ed.), The handbook of affect and social cognition (pp. 410-431). Mahwah, NJ: Erlbaum.

Mayer, J. D. (2007). Personality: A systems approach. Boston: Allyn \& Bacon.

Mayer, J. D., \& Geher, G. (1996). Emotional intelligence and the identification of emotion. Intelligence, 22, 89-113. https://doi.org/10.1016/S0160-2896(96)90011-2

Mayer, J. D., \& Salovey, P. (1997). What is emotional intelligence? In P. Salovey \& D. J. Sluyter (Eds.), Emotional development and emotional intelligence: Educational implications (pp. 3-34). New York: Basic Books.

Mayer, J. D., Caruso, D. R., \& Salovey, P. (1999). Emotional intelligence meets standards for traditional intelligence. Emotional Intelligence, 27, 267-298. https://doi.org/10.1016/S0160-2896(99)00016-1

Mayer, J. D., Caruso, D. R., \& Salovey, P. (2000). Selecting a measure of emotional intelligence. In R. Bar-On \& J. Parker (Ed's.), The Handbook of emotional intelligence. San Francisco: Jossey-Bass.

Mayer, J. D., DiPaolo, M., \& Salovey, P. (1990). Perceiving affective content in ambiguous visual stimuli: a component of emotional intelligence. Journal of Personality Assessment, 54, 772-781. https://doi.org/10.1080/00223891.1990.9674037

Mayer, J. D., Salovey, P., \& Caruso, D. (2002). MSCEIT user's manual. Toronto, ON: Multi-Health Systems.

Mayer, J. D., Salovey, P., Caruso, D. R., \& Sitarenios, G. (2003). Measuring emotional intelligence with the MSCEIT. Emotion, 3, 97-105. https://doi.org/10.1037/1528-3542.3.1.97

Mc Adams, D. P. (2006). The Person: A new introduction to personality psychology. Hoboken, NJ: John Wiley \& Sons.

McCrae, R. R., \& John, O. P. (1992). An introduction to the five-factor model and its applications. Journal of Personality, 60, 175-215. https://doi.org/10.1111/j.1467-6494.1992.tb00970.x

McCrae, R..R., \& Costa, E.T. (1986). Personality coping, and coping effectiveness in an adult sample. Journal of Personality, 54, 385-405. https://doi.org/10.1111/j.1467-6494.1986.tb00401.x 
Big five personality factors and emotional intelligence among university students: A gender perspective

Mishra, R., \& Ranjan, P. (2008). Emotional intelligence as related to self-esteem of adolescents. Indian Journal of Human Relation, 34, 13-17.

Miville, M. L., Carlozzi, A .F., Gushue, G. V., Schara, S. L. (2006). Mental health counselor qualities for a diverse clientele: Linking empathy, universal diverse orientation and emotional intelligence. Journal of Mental Health Counselling, 28(2), 151-165. https://doi.org/10.17744/mehc.28.2.6khc06t87c2fr7y3

Mohanty, I., \& Devi, U. L. (2010). Socio-personal variables and emotional Intelligence of adolescents in secure attachment style. Indian Psychological Review, 74(1), 29-37.

Mohsin, A., Ather, M., \& Bano, M. (2013).Emotional intelligence and personality traits among university teachers: Relationship and gender differences. International Journal of Business and Social Science, 4(17), 253-259.

Mount, M. K., \& Barrick, M. R. (1998). Five reasons why the "Big Five" Article has been frequently cited. Personnel Psychology, 51, 849-857. https://doi.org/10.1111/j.1744-6570.1998.tb00743.x

Myers, D.G. (1998). Psychology (5 ${ }^{\text {th }}$ ed.). New York: Worth Publishers.

Myleen, L., Michael, R., \& William, F. (2009). A study of personality preferences and emotional intelligence. Leadership and Organization Development Journal, 30(4), 421-434.

Narimani, M., Babazadeh, K. M., \& Saeid, F. (2007). Examining personality traits and job satisfaction of employees. Scientific Journal of Ardabil University of Medical Sciences, 4(1), 77-83.

Nasar, R., and Nasar, Z. (2008) Emotional Intelligence and creativity. Indian Psychological Review, 71, 251-254.

Ozer, D. J., \& Benet-Martinez, V. (2006). Personality and the prediction of consequential outcomes. Annual Review of Psychology, 57, 401-421. https://doi.org/10.1146/annurev.psych.57.102904.190127

Pandey, R., \& Tripathi, A. N. (2004). Development of emotional intelligence: Some preliminary observations. Psychological Studies-University of Calicut, 49, 147-150.

Pant, N., \& Prakash, A. (2004). Multifactor emotional intelligence scale in India: An evaluation Psychological studies, 49, 128-135.

Payne, R., Minasian, K.C., \& Foster,L.(1984). The world's whales the complete illustrated guide. Washington, D. C.: Smithsonian Books.

Pervin, L. A., Cervone, D., \& John, O. P. (2005). Personality: Theory and research (9th ed.). Hoboken, NJ: John Wiley \& Sons.

Petrides, K. V., \& Furnham, A . (2001). Trait emotional intelligence: Psychometric investigation with reference to established trait taxonomies. European Journal of Personality, 15(6), 425-448. https://doi.org/10.1002/per.416

Petrides, K. V., Vernon, P. A., Schermer, J. A., Ligthart, L., Boomsma, D. I. \& Veselka, L. (2010). Relationships between trait emotional intelligence and the Big Five in the Netherlands. Personality and Individual Differences, 48, 906-910. https://doi.org/10.1016/j.paid.2010.02.019

Petrides, K. Y., Furham, A., \& Martin, G. N. (2004). Estimates of emotional and psychometric intelligence: evidence for gender- based stereotypes. Journal of Social Psychology, 144(2), 149-162. https://doi.org/10.3200/SOCP.144.2.149-162

Piderit, S. K. (2000). Rethinking resistance and recognizing ambivalence: A multidimensional view of attitudes toward an organizational change. The Academy of Management Review, 25(4), 783-794.

Pusey, P. L. (2000). The role of water in epiphytic colonization and infection of pomaceous flowers by Erwinia amylovora. Phytopathology, 90, 1352-1357. https://doi.org/10.1094/PHYTO.2000.90.12.1352

Rahmani, S., \& Lavasani, M. G. (2012). Gender differences in five factor model of personality and sensation seeking. Procedia - Social and Behavioral Sciences, 46, 2906-2911.

https://doi.org/10.1016/j.sbspro.2012.05.587

Rice, C.L. (1999). A quantitative study of emotional intelligence and its impact on team performance. (Unpublished master's thesis). Pepperdine University.

Sackett, P. R., Gruys, M. L., \& Ellingson, J. E. (1998). Ability-personality interactions when predicting job performance. Journal of Applied Psychology, 83(4), 545-556.

https://doi.org/10.1037/0021-9010.83.4.545

Saklofske, D. H., Eustin, E. J., \& Minski, P. S. (2003). Factor structure and validity of a trait emotional 
intelligence measure. Personality and Individual Difference, 34, 1091-1100. https://doi.org/10.1016/S0191-8869(02)00056-9

Saklofske, D., Elizabeth J. A., \& Paul, M. (2003). Factor structure and validity of a trait Emotional Intelligence measure. Personality and Individual Differences, 34(4), 707-721. https://doi.org/10.1016/S0191-8869(02)00056-9

Sala, F. (2002). Emotional competence inventory: Technical manual. Philadelphia, PA: McClelland Center for Research.

Salgado, J. F. (1997). The five-factor model of personality and job performance in the European Community. Journal of Applied Psychology, 82, 30-43. https://doi.org/10.1037/0021-9010.82.1.30

Salgado, J. F. (2003). Predicting job performance using FFM and non-FFM personality measures. Journal of Occupational and Organizational Psychology, 76, 323-346. https://doi.org/10.1348/096317903769647201

Salovey, P., \& Mayer, J. D. (1990). Emotional intelligence. Imagination, Cognition, and Personality, 9, 185-211. https://doi.org/10.2190/DUGG-P24E-52WK-6CDG

Samuel, S. (2011). Personality and psychological well-being of adolescents: The moderating role of emotional intelligence. Social Behavior and Personality, 39(6), 785-794. https://doi.org/10.2224/sbp.2011.39.6.785

Saranya, R., \& Velayudharn, A.(2008) Analysing prosocial behavior and emotional intelligence among university students. Psycho-lingua, 38(2), 126-132.

Schutte, N. S., Malouff, J. M., Hall, L. E., Haggerty, D. J., Cooper, J. T., Golden, C. J., et al. (1998). Development and validation of a measure of emotional intelligence. Personality and Individual Differences, 25, 167-177. https://doi.org/10.1016/S0191-8869(98)00001-4

Shulman, E.T., \& Hemenover, S.H. (2006). Is dispositional emotional intelligence synonymous with personality? Self and Identity, 5, 147-171. https://doi.org/10.1080/15298860600586206

Sternberg, R. J., \& Grigorenko, E. L. (2000). Practical intelligence and its development. In R. Bar-On \& J. D. A. Parker (Eds.), The handbook of emotional intelligence (pp. 215-243). San Francisco: Jossey-Bass. https://doi.org/10.1017/CBO9780511807947

Tatwawadi, S. (2009). Emotional maturity of management student. Psycholingua, 39(1), 78-82.

Thingujam, N. S., \& Ram, U. (2000). Emotional Intelligence Scale: Indian norms. Journal of Education and Psychology, 58, 40-48.

Thorndike, E.L. (1920). Intelligence and its use. Harper's Magazine, 140, 227-235.

Trull, T. J., \& Sher, K. J. (1994). Relationship between the five-factor model of personality and Axis I disorders in a nonclinical sample. Journal of Abnormal Psychology, 103(2), 350-360. https://doi.org/10.1037/0021-843X.103.2.350

Tyagi, S. K. (2004). Emotional intelligence of secondary teacher in relation to gender and age. Indian Educational Abstracts, 41(3), 39-45.

Van Rooy, D. L., \& Viswesvaran, C. (2004). Emotion intelligence: A meta-analytic investigation of predictive validity and nomological net. Journal of Vocational Behavior, 65, 71-95. https://doi.org/10.1016/S0001-8791(03)00076-9

Van Rooy, D. L., Alanso, A., \& Viswesvaran, C. (2005). Group differences in emotional intelligence scores: Theoretical and practical implications. Personality and Individual Differences, 38(3), 689-700. https://doi.org/10.1016/j.paid.2004.05.023

Van, D. Z., Thijs, M., \& Schakel, L. (2002). The relationship of emotional intelligence with academic intelligence and the big five. European Journal of Personality, 16, 103-125. https://doi.org/10.1002/per.434

Weinberg, R. S., \& Gould, D. (1999). Personality and sport. Foundations of sport and exercise psychology. Champaign, IL: Human Kinetics

Widiger, T. A. (2005). Five factor model of personality disorder: Integrating science and practice. Journal of Research in Personality, 39(1), 67-83. https://doi.org/10.1016/j.jrp.2004.09.010

Yusooff, F., Desa, A., Ibrahim, N., Kadir, N. B. A., \& Rahman, R. M. (2014). A study of the relationship between 
Big five personality factors and emotional intelligence among university students: A gender perspective

EQ and personality among lecturers at a research university. Procedia - Social and Behavioral Sciences, 114, 351-354. https://doi.org/10.1016/j.sbspro.2013.12.710

Zadel, A. (2004). Impact of personality and emotional intelligence on successful training in competences. Managing Global Transitions, 4(4), 363-376.

Zee, V. K., \& Wabeke, R. (2004). Is trait-emotional intelligence simply or more than just a trait? European Journal of Personality, 18, 243-263. https://doi.org/10.1002/per.517 